DOl: $10.19195 / 2353-8546.8 .10$

\author{
AGATA FIRLEJ* \\ Uniwersytet im. Adama Mickiewicza (Poznań, Polska) \\ ORCID: 0000-0002-3928-1079
}

\title{
Don Kichoci, Podziemni i Rewizjoniści. Postawy środkowoeuropejskich pisarzy wobec wolności
}

\begin{abstract}
Don Quixotes, Undergrounders, and Revisionists. Central European writers' attitudes to freedom. The article uses comparative methodology and juxtaposes the attitudes of Polish, Czech and, to a lesser extent, Ukrainian authors towards freedom obtained after 1989. The author distinguishes three main attitudes, calling them "Don Quixotes", "Undergrounders" and "Revisionists". The first type is related to retrotopic thinking and means attempts to mystify reality in order to counteract the degradation of the writer's role in society. Don Quixotes try to fight the rules of the new postcommunistic time, emphasizing their role in the idealized past. The writers associated with the underground during the communism, such as Yuri Andrukhovych, Jáchym Topol, Petr Placák or Tomasz Jastrun, react differently: they are sensitive to attempts of political misusing of the works of culture. The younger generation of authors, called in this text "Revisionists", born most often after the collapse of totalitarianism, tries to revise the social discourse and historical myths and express all what has been so far unspoken and "rotting". This formation includes, among others, Radka Denemarková, Kateřina Tučková, Magdalena Platzová or Stanislav Biler.
\end{abstract}

Keywords: posttotalitarianism, underground, revisionism, retrotopia, freedom

* Adres do korespondencji: Instytut Filologii Słowiańskiej UAM w Poznaniu, ul. Fredry 10, 61-701 Poznań. E-mail: afirlej@amu.edu.pl. 
Koniec świata był już dawno... Tylko że do guberni n...skiej każda nowość dochodzi z takim opóźnieniem, że nie ma co mówić. Były jakieś plotki, ale potem wszyscy o nich zapomnieli i żyli sobie dalej, jak zawsze.

Ivan Wernisch

Ciekawych metafor do pokazania, czym jest obciążenie posttotalitarne kolejnych pokoleń, dostarczyła po 1989 roku Bułgaria. Václav Havel w swoim przemówieniu wygłoszonym podczas wręczenia Nagrody świętego Wojciecha w Bratysławie w 1999 roku opowiadał:

Znalazłem niedawno w gazecie informację, która natychmiast przykuła moją uwagę. Bułgarzy chcieli wysadzić w powietrze mauzoleum niegdysiejszego komunistycznego przywódcy Dymitrowa. Pirotechnicy naszpikowali budowlę odpowiednią ilością środków wybuchowych, odpalili ładunek i nic się nie stało. Budowla wytrzymała, jedynie tylko lekko się zachwiała. [...] Tak, właśnie tak jest: nie możemy tak po prostu wysadzić w powietrze naszej przeszłości i pozbyć się jej raz na zawsze ${ }^{1}$.

Druga metaforyczna sytuacja została opisana przez Witolda Szabłowskiego we wstępie do wydanej w 2018 roku książki Tańczace niedźwiedzie. Reportażysta opisuje „laboratorium wolności” dla niedźwiedzi odebranych po wejściu do Unii Europejskiej (2007) bułgarskim niedźwiednikom, którzy utrzymywali się z — często brutalnej - tresury tych zwierząt do sztuczek cyrkowych. Jedna z austriackich organizacji działających na rzecz praw zwierząt zorganizowała w Belicy niedaleko Sofii specjalny ośrodek, w którym niedźwiedzie nieznające wolności miały się jej stopniowo uczyć. Była to, wylicza Szabłowski, nauka „jak wolny niedźwiedź powinien się poruszać. Jak powinien zabiegać o swoją przyszłość. Jak hibernować. Jak kopulować. Jak zdobywać jedzenie”. Przedsięwzięcie przez większość czasu działało z sukcesem, ale jak się okazało:

każdy emerytowany tańczący niedźwiedź ma taki moment, kiedy wolność zaczyna go boleć. Co wtedy robi? Staje na tylnych łapach i zaczyna... tańczyć. Odtwarza to, czego pracownicy parku za wszelką cenę chcą go oduczyć. Odtwarza zachowania niewolnika. Woła tresera, żeby wrócił i znów wziął odpowiedzialność za jego życie. „Niech bije, niech źle traktuje, ale niech zabierze tę cholerną konieczność radzenia sobie z własnym życiem" - zdają się mówić niedźwiedzie. I znów pomyślałem, że to niby opowieść o niedźwiedziach. Ale też o nas².

1 „Četl jsem nedávno v novinách zprávu, která mne okamžitě zaujala. V Bulharsku chtěli zničit mauzoleum někdejšího komunistického vůdce Dimitrova. Pyrotechnici uložili do budowy př́slušné množství trhaviny, nálož odpálili - a nic se nestalo. Budova se nezhroutila, pouze se lehce naklonila. [...] Ano, je tomu tak: svou vlastní minulost nemůžeme jen tak vyhodit do povětří, a tím se jí jednou provždy zbavit". V. Havel, Projevy a jinétexty 1999-2006. Prosímstručně. Odcházení. Spisy/8, Praha 2007 [przeł. A.F.].

${ }^{2}$ W. Szabłowski, Tańczące niedźwiedzie, Warszawa 2018, s. 9, 11. 
Historia ośrodka w Belicy jest dla Szabłowskiego punktem wyjścia do opowieści o znajdujących obecnie posłuch „rewolucjonistach” (populistach), obiecujących retrotopiczny powrót do komfortu w zamian za posłuszeństwo. Lapidarnie ujął to swego czasu Andrzej Stasiuk w Jadąc do Babadag: „Wszyscy jesteśmy osieroconymi dziećmi jakiegoś cesarza czy dyktatora"3. Retrotopia, czyli rzutowanie wizji utopijnych na przeszłość, w której miał istnieć jakiś „złoty wiek” stabilności i prosperity pod wodzą dobrego pana - cesarza czy dyktatora - została opisana przez Zygmunta Baumana w jego ostatniej książce pod takim właśnie tytułem (Retrotopia). Refleksja naukowa nad tym zjawiskiem dopiero się rozpoczyna, ale w dyskursie społecznym i w sztuce retrotopia istnieje od dawna; jej podstawowy budulec, nostalgia, zwykle poprzedza rewolucję, jak dowodzi harvardzka slawistka i komparatystka Swietłana Boym, na którą Bauman powołuje się w swoich wstępnych ustaleniach. Badaczka podaje jako przykład rewolucję francuską, argumentując: „Nie tylko ancien régime wyzwalał rewolucję, ale w pewnym sensie rewolucja wytwarzała ancien régime, nadając mu kształt, wrażenie ekskluzywności i aurę świetności”4. Kiedy trudną teraźniejszość rzutuje się na niepewną i potencjalnie jeszcze trudniejszą przyszłość, jako jedyna alternatywa, w której można ulokować tęsknotę za bezpieczeństwem, pojawia się przeszłość. Zygmunt Bauman wyjaśnia ten mechanizm, posługując się nawiązaniem do opartej na pomyśle Waltera Benjamina interpretacji rysunku Paula Klee Angelus novus z 1920 roku. Zgodnie z tym odczytaniem anioł z przerażeniem podąża ku przyszłości, popychany przez wiatr od strony raju, ale obrócony jest ku przeszłości: leci tyłem. To przeszłość jest dla niego rajem. Można powiedzieć, że retrotopia jest podłożem rewolucji „wstecznej” w przeciwieństwie do bezprzymiotnikowej rewolucji, która zawsze opiera się na dążeniu do utopijnej „świetlanej przyszłości”. Nad wykorzystaniem kategorii gramatycznej czasu zastanawia się czeski prozaik Jaroslav Rudiš w książce Konec punku $v$ Helsinkách, w której powracającym motywem jest nieistnienie teraźniejszości, szczególnie widoczne w odczytywanych przez głównego bohatera sloganach partyjnych (za komunizmu) i hasłach reklamowych (za kapitalizmu). Jak można wyczytać w powieści, jedyny slogan dotyczący teraźniejszości umieszczono nad wejściem do szpitala dla umysłowo i nerwowo chorych i brzmiał

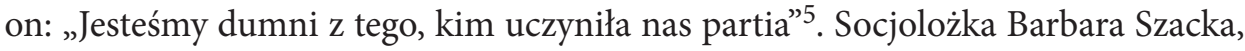
zajmująca się pamięcią zbiorową, sformułowała pogląd, że przeszłość sakralizuje teraźniejszość ${ }^{6}$ - wobec czego z teraźniejszością w dyskursie społecznym albo nie mamy do czynienia w ogóle, albo nie mamy do niej realnego dostępu, bo jest ona poddana manipulacji.

3 A. Stasiuk, Jadąc do Babadag, Wołowiec 2004, s. 24.

4 "Not only the ancienrégime produced revolution, but in some respect the revolution produced the ancienrégime, giving it a shape, a sense of closure and a gilded aura". Z. Bauman, Retrotopia, Cambridge 2017, s. 10 [przeł. A.F.].

${ }^{5}$ J. Rudiš, Koniec punku w Helsinkach, przeł. K. Dudzic, Wrocław 2013, s. 67.

${ }^{6}$ B. Szacka, „O pamięci społecznej”, Znak 1995, nr 5, s. 76. 
Myślenie retrotopiczne towarzyszy rewolucji („retrorewolucji”?) i wytwarza postawę, którą można by nazwać „syndromem Don Kichota” w nawiązaniu do siedemnastowiecznej powieści Cervantesa, pisanej zresztą w więzieniu. Tytułowy bohater utworu, jak wiadomo, spóźnił się na epokę rycerską, jednak nie przyjął tego do wiadomości: uznał się za rycerza i zaczął widzieć olbrzymy w wiatrakach, domagać się pochwał dla prostej wieśniaczki przemianowanej na piękną Dulcyneę, a miskę balwierską brał za wielce pożądany czarodziejski hełm Mambrina. Spalenie biblioteki szlachcica - czyli metaforyczne usunięcie toksycznej narracji o świetnej rycerskiej przeszłości - nic nie daje; Don Kichot pozostaje „zaczarowany” niemal aż do samej śmierci. Jego życie przebiega pod hasłem obrony fałszywej tożsamości zbudowanej z przeszłych legend oraz trwania w iluzji za wszelką cenę (a czasem i przy staraniach publiczności).

Syndrom Don Kichota pomaga opisać stan, jaki totalitaryzm, a następnie transformacja wywołała wśród części środkowoeuropejskich twórców kultury. Uzyskanie wolności po 1989 roku było wstrząsem o dużej dozie ambiwalencji. Z jednej strony naturalnie przełom wywołał entuzjazm pisarzy i artystów, którzy o wolność walczyli $\mathrm{z}$ absolutnym poświęceniem, $\mathrm{z}$ drugiej: dość szybko okazało się, że nowe czasy nie potrzebują już dawnych artystów i pisarzy, a ich dzieła zostają odrzucone jako towar gorszego sortu na komercyjnym targowisku (p)różności. Jiří Holý w odniesieniu do kontekstu czechosłowackiego opisywał je tak:

Nastąpiła wolność, o której marzyło kilka pokoleń czeskich pisarzy. Jednak wraz z nią przyszedł niebywały chaos w kulturze, ponieważ na rynku pojawiły się książki z różnych okresów i rozmaitych wartości, publikacje podziemne, emigracyjne, dzieła przez dziesięciolecia pozostające w rękopisach i sezonowe nowości. Pavel Janoušek określił ten chaos słowami: „stare kryteria już nie obowiązują, a nowe jeszcze nie istnieją ${ }^{7}$.

Jeszcze wcześniej filozofka Jolana Poláková w swojej krytycznej wobec postmodernizmu książce Perspektivv a naděje pisała o „reakcji obronnej” twórców, którzy nie mogą się godzić na zewnętrzny przymus odejścia od „orientacji transcendentalnej”8. Tomasz Jastrun w swojej Rzece podziemnej komentował:

Już na progu naszej wolności wiedziałem, że nie bardzo nam ta wolność wychodzi. I że jesteśmy chorzy. Pocieszałem się, że choroby narodowe są nietypowe, nikt nie zna ich przebiegu i tego, jakie są rokowania, więc może kiedyś okaże się, że ta przypadłość to był bieg po zdrowie??

Z dnia na dzień luminarze kultury przestali być luminarzami (rycerzami?), stracili na znaczeniu i przystąpili do nierównej walki z wiatrakami rynku, agresywną nowoczesnością, ignorancją nowej epoki. Iluzja, jaką z całej siły starali się podtrzymywać, polegała na przeświadczeniu, że w czasach totalitaryzmu ich twórczość rzeczywiście miała wielkie znaczenie. Budując taki mit, Don Kichoci ignorują fakt, że

\footnotetext{
7 J. Holý et al., Česká literatura od počátků k dnešku, Praha 2006, s. 923-924.

8 J. Poláková, Perspektivy a naděje. Hledání transcendence v postmoderní době, Praha 1995.

9 T. Jastrun, Rzeka podziemna, Warszawa 2005.
} 
zarówno teksty i artefakty należące do oficjalnego nurtu, jak i te, które mu się aktywnie sprzeciwiały, w rzeczywistości zredukowane były do wymowy ideologicznej, czyli w pewnym sensie: zniewolone. Demoniczność totalitaryzmu polega na tym, że nie sposób było uniknąć takiej redukcji i stąd wynikała późniejsza szybka dezaktualizacja wielu utworów tamtego czasu. Jedynie twórcy radykalnie undergroundowi, tak jak wcześniej rosyjscy konceptualiści, próbowali uniknąć tej pułapki, świadomie i konsekwentnie odrzucając tak zwane zaangażowanie, jednak i oni niejednokrotnie ponosili porażkę, ponieważ, jak tłumaczył Václav Havel w rozmowie z Karlem Hvižd’alą: „totalitaryzm działa tak, że w nim wszystko jest polityczne, nawet koncert rockowy" 10 . Jedynym narzędziem walki z totalitaryzmem „dowartościowującym” kulturę poprzez zredukowanie jej do celów i odczytań ideologicznych była, zgodnie z przeświadczeniem twórców undergroundowych, całkowita wolność sztuki $\mathrm{w}$ tym miejscu undergroundowcy spotykali się z awangardą.

Współczesna ucieczka części twórców kultury od wolności realizuje się poprzez analogiczny powrót do ideologicznych zaangażowań czy też do „realizmu medialnego", jak to określała Maria Janion: „Chodzi przede wszystkim o kreację oryginalnego języka artystycznego, a tymczasem w literaturze panuje tak zwany realizm medialny, naśladujący $\mathrm{w}$ istocie reportaże telewizyjne" ${ }^{\prime 1}$. To samo dotyczy również recepcji, mechanizmów odbioru kultury, które nawet dzieła wielowarstwowe i uniwersalne sprowadzają do wymowy ideologicznej (taki typ odbioru wspierany jest już przez szkolną edukację).

Wypowiedzi trzech autorów: z Ukrainy (Jurij Andruchowycz), Czech (Jáchym Topol) i Polski (Tomasz Jastrun), uzyskane na użytek niniejszego artykułu, pozwalają dostrzec wyczulenie twórców o przeszłości podziemnej i undergroundowej na próby ideologicznego zawłaszczania literatury. Wymienionych twórców, będących prozaikami, poetami i publicystami, łączą zbliżony wiek (Tomasz Jastrun jest o dekadę starszy, ale należy do tej samej formacji), karta opozycyjna w czasach totalitaryzmu oraz kontynuacja twórczości literackiej już po 1989 roku. Wydaje się uzasadnione przytoczenie ich obszerniejszych wypowiedzi dla możliwie pełnego zaprezentowania podobieństw i odmienności w traktowaniu kwestii „zaangażowania” i „roli pisarza”.

Jáchym Topol, dawniej ważny twórca undergroundowy, współtwórca podziemnego „Revolver revue”, następująco diagnozuje obecne tendencje w kulturze i społeczeństwie, powołując się na własne doświadczenia:

Długo pracowałem jako dziennikarz, który musiał w swoich artykułach i reportażach zajmować się polityką, więc zawsze cieszyłem się, że pisząc prozę będę mógł pofantazjować i oderwać się od polityki - ale chyba nigdy mi się to nie udało. Moją ostatnią powieść, Wrażliwy człowiek, z powodów politycznych skrytykował w druku znany czeski polityk, eksprezydent Václav Klaus. Dlaczego? Jemu i jego współpracownikom, którzy też się podpisali pod tym tekstem z niewiarygodnym podtytułem „Czy pisarz Jáchym Topol miał prawo napisać powieść Wrażliwy człowiek?”, nie spodobało się to, że

10 „V totalitních pomerrech to tak chodí, že politikou je vlastně všechno, třeba i rockový koncert”. V. Havel, op. cit., s. 305 [przeł. AF].

11 M. Janion, Niesamowita Słowiańszczyzna, Kraków 2006, s. 9. 
moje książki są tłumaczone na obce języki, a ja, zwłaszcza w tej powieści, pokazuję obcokrajowcom Republikę Czeską nie jako raj na ziemi, ale miejsce, w którym mieszkają kłamcy, złodzieje itp. cały ten folklor... To też jest polityka, ten rodzaj patriotyzmu, tak bardzo śmieszny, śmieszny, śmieszny! Polityka, czyli ideologia, jest tak naprawdę już teraz we wszystkim: w opisach wsi kryje się rewolucja klimatyczna, relacje między płciami to istne pole minowe, nie mówiąc już o pisaniu na przykład o Arabach czy Romach, czy innych grupach ludzkich, jeśli człowiek jest akurat $\mathrm{z}$ innej grupy. Książki ocenia się nie po tym, o czym tam piszesz, ale po stopniu sympatii, którą wyrażasz - i jak zawsze znajdą się tacy, co cię kochają (w każdym razie w moim przypadku), ale i tacy, którzy cię zaatakują - co byłoby w porządku, gdyby faktycznie chodziło o literaturę, a nie o wątki ideologiczne. Za naszego życia, więc w ciągu paru lat czy najwyżej dziesięcioleci, literatura zupełnie straci na znaczeniu, zupełnie zniknie, zostaną tylko ideologiczne, polityczne pamflety... Wierzę jednak, że potem „powstaną nowi wojownicy”, a wraz z nimi odrodzi się literatura, pisanie i czytanie literatury... Czyli opowieści. Ta trudna do opisania magia opowieści, w których jak w odbiciu widzimy własne życie i przeczuwamy niezwykłą tajemnicę świata i egzystencji — ech, ależ naplotłem! — znów zacznie się dziać między zwykłymi ludźmi, na marginesie życia społecznego i wbrew komercji - jak jakiś underground. A może to już się dzieje, tylko jeszcze tego nie widać, może nowa literatura ze starą, archetypalną treścią gdzieś już wzrasta, jak delikatna roślinka... tylko jeszcze słabo widoczna na lodowej połaci powszechnego niezainteresowania... Bo literatura to jedna z podstawowych ludzkich potrzeb! To właśnie się okaże! Tego się właśnie dowiemy!... I mam szczęście, bo ta sytuacja mnie ogromnie interesuje i wierzę, że będę przy tym, jak ta roślinka spotężnieje i rozchrzani ten lodowiec...Chociaż nie, może nie, jestem już stary i mogę tego nie dożyć... raczej nie zdążę... ale mogę to sobie przynajmniej do końca życia wyobrażać — to na pewno! ${ }^{12}$

Wrażliwość Jáchyma Topola na ideologizację kultury i próbę kreowania „społecznej roli pisarza" jest charakterystyczna dla czechosłowackich twórców o przeszłości dysydenckiej i undergroundowej.

Na tym tle bardziej zniuansowane wydaje się podejście reprezentowane przez Tomasza Jastruna, opozycjonisty więzionego w czasach stanu wojennego, wieloletniego felietonisty paryskiej „Kultury”, współtwórcy podziemnych wydawnictw, poety i prozaika publikującego intensywnie także już po przełomie. Pisze on tak:

W stanie wojennym pisałem wiersze i prozę, dając świadectwo zdarzeniom i emocjom tamtego czasu. Przez kilkadziesiąt lat piszę felietony, w których wiele jest spraw społecznych i komentarzy do bieżących zdarzeń. Piszę ostro, tak jak myślę. Robię to też teraz, gdy znowu nastał czas smuty. Nie unikam takich tematów w swojej prozie. Wiem, że zaangażowanie w sprawy społeczne i polityczne jest dla literatury bardzo ryzykowne. Mało wierszy ze stanu wojennego przeszło próbę czasu. Nie jestem na bieżąco z młodą prozą, nie wiem, na ile daje świadectwo naszym czasom, ale literatura zawsze towarzyszyła małej i dużej historii, co było ważne zarówno dla literatury, jak i dla historii. Obecnie na pewno bardzo spadła rola literatury, a pisarze zmaleli i skurczyli się. Inna sprawa, że w czasach PRL-u byli nieproporcjonalnie ważni, często jakby nadmuchami. Ważną rolę odegrał film, jego inwazja, siła... Nie piszę o tym tylko krytycznie, w końcu powstaje wiele dziel wybitnych. Teraz film częściowo zastępuje literaturę, korzystając zresztą z niej obficie; w końcu literatura jest u źródeł kina. Konkursów literackich i festiwali jest teraz wiele, ale chyba jest to przede wszystkim lansowanie książki jako produktu, literatura, powieść przestała być dziełem: jest produktem, bardziej niż kiedykolwiek... Każdy pisze książki — geniusz i głupek, polityk i gangster, każdy jest pisarzem, do tego nie trzeba już umieć pisać... ${ }^{13}$

$12 \mathrm{Z}$ wywiadu korespondencyjnego udzielonego autorce na użytek niniejszego artykułu 7 września 2020 [przeł. A.F.].

$13 \mathrm{Z}$ wywiadu korespondencyjnego udzielonego autorce na użytek niniejszego artykułu 4 września 2020.

Miscellanea Posttotalitariana Wratislaviensia 8, 2020

(C) for this edition by CNS 
W przytoczonych wypowiedziach łatwo dostrzec różnicę polegającą na bardziej aprobatywnym stosunku polskiego twórcy do idei zaangażowania. Tomasz Jastrun, który w swojej świeżo wydanej książce Dom pisarzy w czasach zarazy z przenikliwością analizuje mechanizm ideowej korupcji polskich artystów w okresie stalinizmu, nie odrzuca koncepcji pisarza jako autorytetu moralnego i twórcy albo przekaziciela wielkich idei społecznych ${ }^{14}$. Rozbieżność pomiędzy przedstawionymi opiniami może wynikać między innymi z odmienności sytuacji twórców w Czechosłowacji i Polsce: totalitaryzm, jakiego doświadczył Tomasz Jastrun, a nawet ten, którego doświadczyli jego ojciec, poeta Mieczysław Jastrun, i inni opisywani przez niego twórcy w latach pięćdziesiątych, był mimo wszystko łagodniejszy niż model czechosłowacki, obserwowany od lat siedemdziesiątych przez Jáchyma Topola (a wcześniej przez jego ojca Josefa Topola, opozycyjnego dramaturga). Wniosek ten znajduje potwierdzenie w lekturze wypowiedzi Jurija Andruchowycza, który jako twórca niezależny debiutował w Ukrainie będącej częścią, a nie tylko satelitą Związku Radzieckiego — tam totalitaryzm oddziaływał z największą intensywnością. Pytany o koncepcję zaangażowania Jurij Andruchowycz odpowiada:

O czymś takim jak „rola pisarza” myślałem zawsze sceptycznie, autoironicznie. Zresztą wyśmiałem to w jakiś sposób w swojej pierwszej powieści Rekreacje. Ale w żadnym razie nie usiłowałem trzymać się z dala od tematów, z grubsza rzecz biorąc, politycznych. Najwięcej tego nazbierało się w Moskoviadzie. Jednak i Leksykon ma niektóre rozdziały ściśle „polityczne” - taki Strassburg i wiele innych. Zresztą w drugim wydaniu Leksykonu (polski czytelnik tego nie ma i nie zna) pojawiła się nowa część o Kijowie w czasach Euromajdanu, jest to taki splot osobistego z politycznym. W Waldbercie ${ }^{15}$ docierały do mnie bardzo niepokojące wiadomości - przede wszystkim z Moskwy, ale i z Ukrainy też: że tu i tam idzie ku rewanżowi, że już za chwilę cała ta wolność znowu będzie zlikwidowana i wrócimy do jakiegoś kolejnego ZSRR. Taki permanentny stan bardzo ostrego zagrożenia. No i trzeba coś z tym zrobić - chociażby dla siebie osobiście, jakoś się rozliczyć z tymi strachami przed katastrofą. Czyli pisanie jako autoterapia ${ }^{16}$.

Jurij Andruchowycz jest konsekwentny w odrzucaniu tak zwanej roli społecznej pisarza, co można odczytywać jako reakcję na opisane wyżej właściwości totalitaryzmu, którą dzieli zresztą z innymi ukraińskimi twórcami. Być może jest to - obok skomplikowanej sytuacji politycznej i stałego zagrożenia ze strony Rosji, wymagającej mobilizacji wspólnoty opartej na uproszczonych symbolach i mitach — jedna z przyczyn dostrzeżonej przez Agnieszkę Matusiak rezerwy w przywracaniu pamięci narodowej i kulturowej. Badaczka w książce Wyjść z milczenia. Dekolonialne zmagania kultury i literatury ukraińskiej XXI wieku z trauma posttotalitarna pisze:

Dziś do klasyki tematu należą utwory takie jak Moskoviada, Rekreacje, Dwanaście kręgów Jurija Andruchowycza, Riwne/Rowno Oleksandra Irwancia czy Badania terenowe nad ukraińskim seksem Oksany Zabużko. Wszystko są to jednak teksty, w których pamięć - choć próbuje zapełnić luki na

14 T. Jastrun, Dom pisarzy w czasach zarazy, Warszawa 2020.

15 J.A. przebywał na stypendium twórczym w bawarskiej willi Waldberta w 1992 roku, gdzie napisał swoją drugą powieść Moscoviada.

${ }^{16} \mathrm{Z}$ wywiadów korespondencyjnych udzielonych autorce na użytek niniejszego artykułu 7-8 września 2020.

Miscellanea Posttotalitariana Wratislaviensia 8, 2020

(C) for this edition by CNS 
ukraińskiej karcie memorialnej - wciąż mimo wszystko nie otwiera narodowo-kulturowych szaf z truchłami pamięci, których uparte przetrzymywanie w zamknięciu przez cały okres niezależności Ukrainy przygotowało - w sensie mentalnym - wprowadzenie w 2014 roku, tuż po Euromajdanie, wojsk rosyjskich najpierw na Krym, a potem na Doniecczyznę i Ługańszczyznę ${ }^{17}$.

W czasie odbierania nagrody Vilenica w Słowenii w 2017 roku Jurij Andruchowycz w swoim przemówieniu również podkreślał, że pisarz nie reprezentuje żadnego narodu, a jedynie - siebie. Trudno o bardziej jednoznaczną deklarację niechęci do narzuconych ról i zadań.

Przedstawiony na początku niniejszego artykułu syndrom Don Kichota, definiowany jako przeświadczenie o społecznej i politycznej degradacji pisarza oraz próby przeciwstawiania się regułom nowej epoki, w szerszym sensie - jako znak czasów - przenika do literackich kreacji bohaterów. Przykładem może być Jaroslava Rudiša Národní třída z 2013 roku, wydana w Polsce trzy lata później jako Aleja Narodowa; powieść która znalazła się wśród maturalnych tematów dla czeskich uczniów ${ }^{18}$. Jest to skierowany do syna monolog człowieka, który deklaruje, że działa w myśl zasady „si vis pacem, para bellum” („kdo chce mír, chýstá se k válce”), choć można wątpić w pierwszą część tej deklaracji. Tytuł odsyła do centralnej ulicy w Pradze i zarazem do początku aksamitnej rewolucji (to tu brutalnie stłumiono pierwszą pokojową demonstrację 17 listopada 1989 roku), ale akcja rozgrywa się na peryferiach tego miasta, w gospodzie dla wyrzutków, niedostosowanych i na bakier $\mathrm{z}$ prawem. Jednym $\mathrm{z}$ nich jest narrator, uważający się za ostatniego Rzymianina $\mathrm{z}$ Teutoburskiego Lasu, co jest nawiązaniem do słynnej bitwy z 9 roku, która sprawiła, że granica Imperium Romanum zatrzymała się na Renie. Później historia ta funkcjonowała jako mit założycielski niemieckiego nacjonalizmu (odgrywając zresztą również pewną rolę $w$ okresie reformacji). Bohater Rudiša jest więc wojownikiem, czas walki to jego czas. Powraca plemienność - i to nie jest tylko powieść o współczesnych Czechach, ale i o tendencjach w Europie, na świecie. O wyczuwalnej zmianie, końcu paradygmatu postępu, pozytywnych zmian, końcu epoki optymizmu. Powieść zaczyna się od prowokacyjnego stwierdzenia: „Adolf Hitler uratował mi życie” („Adolf Hitler mi zachránil život”). W kontekście całego utworu można by interpretować to zdanie jako sygnał, że zamiast relacji międzyludzkich istnieją już jedynie ideologie, slogany. Z drugiej strony jest to także wołanie o wodza, führera. Wołanie o wodza, tak jak wołanie o niedźwiednika, o którym opowiada Szabłowski, jest wynikiem poczucia destabilizacji, chaosu. O takiej sytuacji traktują między innymi powieści Jáchyma Topola Sestra z 1994 roku (w Polsce Siostra, 2002) i o rok późniejszy Anděl (polski przekład Anioł, 2006). Pierwsza z powieści pokazuje Pragę okresu transformacji jako dzikie miasto opanowane przez rywalizujące plemiona, $\mathrm{w}$ drugiej podobnie: transformacyjna metafizyka chaosu, zawierająca w sobie sekty, podejrzane

17 A. Matusiak, Wyjść z milczenia. Dekolonialne zmagania kultury i literatury ukraińskiej XXI wieku $z$ trauma posttotalitarna, Wojnowice-Wrocław 2020, s. 85.

18 J. Rudiš, Národní třída, Praha 2013; idem, Aleja Narodowa, przeł. K. Dudzic-Grabińska, Wrocław 2016. 
biznesy, przemoc, pornografię, narkotyki, podróże, bezrobocie. Okazuje się, że nikt nie wie, co zrobić $\mathrm{z}$ nagle zyskaną wolnością. W jednym i drugim przypadku temat ściśle powiązany jest typem narracji, z nową (anty)estetyką, célinowską żonglerką stylistyczną (Céline był jednym z ulubionych twórców czechosłowackiego, polskiego i ukraińskiego undergroundu). Leszek Engelking rejestruje przewagę parataksy nad hipotaksą ${ }^{19}$, odzwierciedlającą według niego rozbicie związków przyczynowo-skutkowych, a może raczej: niemożność odnalezienia ich w chaosie wirujących idei i sytuacji.

Neotrybalizm i wołanie o wodza jako diagnoza literacka przełomu dwudziestego i dwudziestego pierwszego wieku, zatrważająca swoim podobieństwem do okresu sprzed wojen światowych, jest naturalnie przedmiotem zainteresowania badaczy historii i idei. Georges Mink w książce Polska w sercu Europy (2017) pisze:

W 1989 roku bez wątpienia doszło do destabilizacji zarówno punktów odniesienia pamięci zbiorowej, jak i zbiorowych tożsamości. Jest to być może jedna z przyczyn zwrotu w stronę bohaterskiej historii narodowej, znaczonej mocnymi akcentami nacjonalistycznymi. Wielu liderów regionu, nie tylko wywodzących się ze skrajnej prawicy, próbowało na nowo wykorzystywać dawne symbole historii narodowej, będącej już mitem ${ }^{20}$.

W innym miejscu Georges Mink mówi o złożach zmityzowanej pamięci narodowej, które w każdej chwili mogą być wydobyte i wykorzystane do doraźnych celów plemiennych przez charyzmatycznego przywódcę. Prawda ani czasowa odległość nie mają tu żadnego znaczenia; chodzi o symbol i mit.

Tu, znów metaforycznie, można posłużyć się przykładem bitwy w Teutoburskim Lesie: pod koniec XIX wieku pięćdziesięciosześciometrowy pomnik Herrmanna, legendarnego wodza tej bitwy, był jednym z miejsc kultu, centrum mitu założycielskiego niemieckiego nacjonalizmu. Po dwóch wojnach symbol przejęła popkultura i komercja: półmetrowego gipsowego Herrmanna z maleńką szablą stawiano czasem w niemieckich ogrodach w charakterze krasnala. Jednak w powieści Rudiša zarówno bitwa, jak i Herrmann, a także legendarny ostatni Rzymianin na nowo zyskują status symbolu, który działa i opisuje aktualną rzeczywistość, Zeitgeist. Czy to oznacza, że środkowo-wschodnioeuropejski georegion jest skazany na niekończący się cykl powrotów do „niedźwiedziego tańca”? Stefan Themerson pisał w Generale Piesc:

my już naprawdę nie chcemy więcej żadnych zbawców. Wszyscy ci nasi zbawcy, jacy by nie byli, zakłócają normalne ewolucyjne procesy, które i tak, i tak idą swoją własną drogą. Ta droga może być tragiczna. Zazwyczaj jest tragiczna. Ale to, co nasi zbawcy osiągają, kiedy zaczynają się do tych spraw mieszać, to to, że tragedia staje się jeszcze bardziej bolesna ${ }^{21}$.

Przytoczony fragment zawiera przeświadczenie o kontynuacji procesów ewolucyjnych pomimo przeszkód i zakłóceń. Być może dzieje się to już teraz, jeśli świad-

19 L. Engelking, Nowe mity. Twórczość Jáchyma Topola, Łódź 2016, s. 49, 90.

20 G. Mink, Polska w sercu Europy, Kraków 2017, s. 594.

21 S. Themerson, Kardynał Pölätüo. Generał Piesc, Warszawa 2003, s. 195. 
czy o tym pojawienie się nowego, krytycznego dyskursu wśród młodszych czeskich intelektualistów/intelektualistek i artystek/artystów. Radka Denemarková, Kateřina Tučková, Magdalena Platzová, Stanislav Biler, Jaroslav Rudiš, ze starszych: Petr Zelenka czy Jáchym Topol w tekstach literackich i publicystycznych aktywnie i na różne sposoby przeciwstawiają się manipulacjom w obrębie zbiorowej pamięci. Jaroslav Rudiš koduje to w swojej twórczości w formie powracającego motywu kreowania i podtrzymywania iluzji, fałszowania własnych losów przez bohaterów. W jego powieści Grandhotel (2006, polski przekład 2011) niemal każda z postaci mistyfikuje swoją historię; nawet konstrukcja głównego bohatera, którą czytelnik pracowicie sobie wytwarza, w finale okazuje się myląca. Radka Denemarková, Kateřina Tučková, Magdalena Platzová powracają do przemilczanych lub niewystarczająco naświetlonych kart z czeskiej historii (Holocaust, wypędzenia Niemców po II wojnie światowej, tużpowojenne obozy dla Niemców zorganizowane przez Czechów, stłamszona narracja kobieca itp.), budując niejednoznaczne opowieści i stawiając tak zwane niewygodne pytania. Stanislav Biler jako autor debiutu Nejlepší kandidát, którego akcja, rozgrywająca się „po końcu świata”, w czasie pierwszych powszechnych wyborów na czeskiego prezydenta w 2013 roku (wcześniej w tym kraju prezydenta wybierał parlament) pisze satyrę na łatwowierność i niedojrzałość czeskich wyborców. Bardzo podobnym utworem była napisana wiele lat wcześniej sztuka teatralna innego brneńskiego autora, Luboša Baláka - ̌̌vejkův vnuk ${ }^{22}$.

Stanislav Biler jest także publicystą podejmującym w swoich tekstach problematykę rewizji czeskich mitów i przeświadczeń. Jego artykuł Być Czechem - trudna przygoda. Pedagogika wstydu po czesku, przedrukowany po polsku przez „Gazetę Wyborczą" w grudniu 2018 zawierał następującą konstatację:

Pierwsza Republika jest uważana za złoty okres naszego państwa i traktowana jako dowód na to, że gdy Czesi dostaną przestrzeń, potrafią dokonywać rzeczy wielkich i należą do najlepszych na świecie. Przykładem mogą być choćby gospodarcze sukcesy kraju. Nie chcę tego podważać, ale trzeba uściślić: „Jéli Czesi wchodzą w skład wielokulturowego kraju, potrafią dokonywać rzeczy wielkich”. W okresie Pierwszej Republiki Czesi stanowili 51 proc. obywateli, Niemcy natomiast niecałą jedną czwartą, ale przede wszystkim bez nich i bez mniejszości żydowskiej przyzwoita pozycja ekonomiczna wśród państw Europy nie byłaby możliwa. [...] Ówczesna demokracja sprawiała doskonałe wrażenie głównie z zewnątrz. Realną politykę kraju tworzyła grupa skupiona wokół Hradu, co nie jest tożsame z demokracją parlamentarną. Drugim problemowym rysem były więzi elity dziennikarskiej z prezydentem. [...] Wspominamy dostojnego Masaryka, a ignorujemy wszystkich tych, którymi jego państwo się nie zajmowało. Monachium, Protektorat i wojna usunęły w cień udział ówczesnych partii czeskiej prawicy we władzach Drugiej Republiki a potem w rządzie Protektoratu. Jeszcze przed Protektoratem nasze państwo zmierzało wielkimi krokami w stronę reżimu totalitarnego. Ograniczano demokrację i rolę parlamentu, wprowadzano antysemickie i antyromskie rozporządzenia, a także przygotowywano tworzenie obozów pracy ${ }^{23}$.

22 L. Balák, Švejkưvvnuk, Praha 2002.

23 S. Biler, „Być Czechem - trudna przygoda. Pedagogika wstydu po czesku”, Gazeta Wyborcza, 1.12.2018.

Miscellanea Posttotalitariana Wratislaviensia 8, 2020

(C) for this edition by CNS 
Dalej Biler dowodzi, że nieumiejętność zareagowania na kryzys światowy przez rządy Masaryka doprowadziła do radykalizacji Niemców sudeckich (i Monachium), że kryzys władzy wywołany układem partyjnym za Masaryka spowodował po wojnie poparcie dla monopartyjności komunistów, że cenzurę wprowadził w 1945 roku Benesz, by nie krytykowano wypędzenia Niemców. Wniosek Bilera brzmi: Czesi nie są „z natury” demokratyczni, tak jak lubią o sobie sądzić — jest to mit.

Problematyka czeskiej tożsamości zbiorowej była głównym tematem obszernej analizy Jana Čulíka Jsme to my v tom šokujícím zrcadle?24 opublikowanej w tygodniku „Literární nowiny”. Čulík, redaktor czasopisma „Britské listy”, wychodzi w swoim tekście od zreferowania świeżo wówczas wydanej po angielsku historii Czech The State that Failed (Państwo, które zawiodło) Mary Heinmann, w którym bohemistka ukazuje losy kraju, począwszy od dziewiętnastowiecznych koncepcji Palackiego jako dziejów nacjonalistycznego autorytaryzmu i ksenofobii, które nie ustąpiły aż do chwili obecnej i były widoczne nawet w karnawale Praskiej Wiosny ${ }^{25}$. Czescy czytelnicy na ogół odrzucili książkę, zarzucając jej celową nadinterpretację zdarzeń. Tak ostre i natychmiastowe reakcje poniekąd potwierdziły diagnozę Heinmann co do niedojrzałej, ocierającej się o nacjonalizm tożsamości zbiorowej, choć było to zarazem zaskakujące w obliczu gremialnych narzekań artystów (zwłaszcza teatralnych) na niemożność wywołania skandalu wśród czeskich odbiorców, którzy wydają się obojętni na krytyczną narrację. Jan Čulík jest przede wszystkim zainteresowany stawianiem pytań o czeskie społeczeństwo, jego przeświadczenia, pragnienia, więzi, postrzeganie siebie. Podobne pytania pojawią się ponownie w 2008 roku w związku z tak zwaną sprawą Kundery - informacją opublikowaną w czasopiśmie „Respekt” o tym, że dwudziestoletni Milan Kundera na początku lat pięćdziesiątych doniósł bezpiece na Miroslava Dvořáčka, który miał zamiar emigrować z Czechosłowacji; na podstawie tego donosu Dvořáček przesiedział czternaście lat w więzieniu. Sam pisarz później porzucił komunizm, a w 1975 roku wyemigrował i do dziś mieszka we Francji.

Po „sprawie Kundery” projektowano konferencję, w której debacie miały zostać poddane istotne pytania społeczne: rozliczenia z przeszłością komunistyczną, rzeczywista skala problemów podobnych do tych, które zogniskowały się $\mathrm{w}$ „sprawie Kundery", autorytet pisarza i jego przemiany, zasady etyczne i moralne, rola pracy historyków i ocena ich zaangażowania politycznego, formy pracy dziennikarzy ze źródłami historycznymi, zwłaszcza wytwarzanymi przez komunistyczne służby specjalne itp. Ostatecznie, w nieco nerwowej atmosferze, konferencję odwołano, a część przygotowanych już na nią wypowiedzi opublikował kwartalnik „Souvislosti. Revue pro literaturu a kulturu" $(4,2009)$. Szerszą analizę zaproponował Martin C. Putna w szkicu Kauza Kundera (ne)ztracena aneb O jedne neuskutečněné konferencji ${ }^{26}$. Ten

24 J. Čulik, „Jsme to my v tom šokujícím zrcadle?”, Literárky v síti, 26.10.2009.

25 M. Heimann, Czechoslovakia. The State that Failed, London 2009.

26 M.C. Putna, „Kauza Kundera (ne)ztracena aneb. O jedne neuskutečněné konferencji”, Souvislosti 2009, nr 4, http://souvislosti.cz/clanek.php?id=964 (dostęp: 1.10.2020). 
historyk literatury i krytyk literacki, autor m.in. monografii Česká katolická literatura $v$ evropském kontekstu, jak również prac o Václavie Havlu, jako reprezentant naukowców pragnących zerwać z produkcją społecznych mitów otrzymał swego czasu odmowę nadania tytułu profesorskiego przez prezydenta Miloša Zemana. Putna opatruje swój szkic o „sprawie Kundery” zaczerpniętą z Ewangelii puentą: „Więc się nie bójcie! Nie ma bowiem nic zakrytego, co by nie miało być wyjawione, ani nic tajemnego, o czym by się nie miano dowiedzieć" (Mat. 10.26), formułując w nim zarzuty przyzwolenia na społeczną hipokryzję i niechęć do konfrontacji z rzeczywistością posttotalitarnego PTSD. Dekadę temu podobną diagnozę społeczną przedstawiła lapidarnie pisarka Radka Denemarková: „Czechy są chore od stóp do głów, a co gorsza, nie chcą się leczyć. [...] Niewypowiedziane gnije pod dywanem, gdzie podmiata się wszystkie świństwa"27.

Obserwacja czeskiego środowiska literackiego pozwala dostrzec ślady pewnej zmiany: młodsze pokolenie twórców, urodzone najczęściej już po upadku totalitaryzmu, odmiennie postrzega pozycję pisarza, nie stara się unikać diagnoz politycznych, społecznych, usiłuje rewidować historyczne mity, wypowiadać to, co niewypowiedziane i „gnijące”. Nieco starsi od nich twórcy z przeszłością undergroundową, choć - tak jak Jáchym Topol czy Petr Placák — nie uciekają od podobnych problemów, reagują niechęcią na próby jednoznacznie „ideologicznego” odczytywania ich utworów, wrażliwi na wszelkie próby zawłaszczania i redukowania tej wieloznacznej i migotliwej materii. Obie formacje spotykają się w jednym punkcie: jest nim wiara w literaturę jako jedną z podstawowych ludzkich potrzeb.

\section{Bibliografia}

Andruchowycz, Jurij. 1995. Rekreacje. Przeł. Ola Hnatiuk. Izabelin: Świat Literacki.

Andruchowycz, Jurij. 2000. Moscoviada. Powieść grozy. Przeł. Przemysław Tomanek. Wołowiec: Czarne. Balák, Luboš. 2002. Švejkưvvnuk. Praha: Národnídivadlo.

Bauman, Zygmunt. 2017. Retrotopia. Cambridge: Polity Press.

Biler, S. 2018. „Być Czechem - trudna przygoda. Pedagogika wstydu po czesku”, Gazeta Wyborcza, 1 grudnia.

Biler, Stanislav. 2017. Nejlepší kandidát. Praha: Druhéměsto.

Čulik, Jan. 2009. „Jsme to my v tom šokujícímzrcadle?”, Literárky v síti, 26 października.

Czapliński, Przemysław. 2004. Efekt bierności. Literatura w czasie normalnym. Kraków: Wydawnictwo Literackie.

Engelking, Leszek. 2016. Nowe mity. Twórczość Jáchyma Topola. Łódź: Wydawnictwo UŁ.

Havel, Václav. 2007. Projevy a jinétexty 1999-2006. Prosímstručně. Odcházení. Spisy/8. Praha: Torst.

Heimann, Mary. 2009. Czechoslovakia. The State that Failed. London: Yale University Press.

Holý, Jiř́ et al. 2006. Česká literatura od počátků k dnešku. Praha: Lidovénoviny.

Janion, Maria. 2006. Niesamowita Słowiańszczyzna. Kraków: Wydawnictwo Literackie.

27 „Čechy jsou od hlavy po paty nemocné a co je horší, nechtějí se léčit. [...] Nepojmenované hnije pod kobercem, kam všechna svinstva zametáme". L. Kolouchová, Wywiad z Radka Denemarkovą, ticketpro.cz/jnp/divadlo/cinohra/306541penize-od-hitlera.html (dostęp: 15.08.2020) [przel. AF].

Miscellanea Posttotalitariana Wratislaviensia 8, 2020

(C) for this edition by CNS 
Jastrun, Tomasz. 2005. Rzeka podziemna. Warszawa: Czarna Owca.

Jastrun, Tomasz. 2020. Dom pisarzy w czasach zarazy. Warszawa: Czarna Owca.

Kolouchová, Lucie. 2010. Wywiad z Radka Denemarkovą, ticketpro.cz/jnp/divadlo/cinohra/306541penize-od-hitlera.html (dostęp 15.08.2020).

Matusiak, Agnieszka. 2020. Wyjść z milczenia. Dekolonialne zmagania kultury i literatury ukraińskiej XXI wieku $z$ trauma posttotalitarną. Wojnowice-Wrocław: KEW.

Mink, Georges. 2017. Polska w sercu Europy. Kraków: Wydawnictwo Literackie.

Platzová, Magdaléna. 2006. Aaroniv skok. Praha: Torst.

Poláková, Jolana. 1995. Perspektivy a naděje. Hledání transcendence v postmoderní době. Praha: Vyšehrad.

Putna, Martin C. 2009. „Kauza Kundera (ne)ztracena aneb O jedne neuskutečněné konferencji”, Souvislosti 4, http://souvislosti.cz/clanek.php?id=964 (dostęp 1.10.2020).

Rudiš, Jaroslav. 2006. Grandhotel. Praha: Labyrint.

Rudiš, Jaroslav. 2010. Konec punku v Helsinkách. Praha: Labyrint.

Rudiš, Jaroslav. 2013. Koniec punku w Helsinkach. Przeł. K. Dudzic. Wrocław: Książkowe Klimaty.

Rudiš, Jaroslav. 2013. Národní třída. Praha: Labyrint.

Rudiš, Jaroslav. 2016. Aleja Narodowa. Przeł. K. Dudzic-Grabińska. Wrocław: Książkowe Klimaty.

Stasiuk, Andrzej. 2004. Jadac do Babadag. Wołowiec: Czarne.

Szabłowski, Witold. 2018. Tańczące niedźwiedzie. Warszawa: Agora.

Szacka, Barbara. 1995. „O pamięci społecznej”, Znak 5: 68-77.

Themerson, Stefan. 2003. Kardynał Pölätüo. Generat Piesc. Warszawa: Iskry.

Topol, Jáchym. 1994. Sestra. Brno: Host.

Topol, Jáchym. 1995. Anděl. Praha: Alois Hynek.

Tučková, Kateřina. 2009. Vyhnání Gerty Schnirch. Brno: Host.

Przyjęto do druku/Accepted for publication: 30.08.2020

Miscellanea Posttotalitariana Wratislaviensia 8, 2020

(C) for this edition by CNS 